\title{
Macro Governance and Profitability around the World: A Methodological Improvement
}

\author{
Vince Hooper ${ }^{1}$, Yan Liu², Ah Boon Sim², Asfandyar Uppal ${ }^{2}$ \\ ${ }^{1}$ Xiamen University, Kuala Lumpur, Malaysia \\ ${ }^{2}$ School of Banking and Finance, University of New South Wales, Sydney, Australia \\ Email: hooper.vince@xmu.edu.my, j.liu@unsw.edu.au, a.sim@unsw.edu.au, asfandyar.uppal@unsw.edu.au
}

How to cite this paper: Hooper, V., Liu, Y., Sim, A.B. and Uppal, A. (2019) Macro Governance and Profitability around the World: A Methodological Improvement. Open Journal of Business and Management, 7, 1504-1524.

https://doi.org/10.4236/ojbm.2019.73104

Received: June 12, 2019

Accepted: July 26, 2019

Published: July 29, 2019

Copyright $\odot 2019$ by author(s) and Scientific Research Publishing Inc. This work is licensed under the Creative Commons Attribution International License (CC BY 4.0).

http://creativecommons.org/licenses/by/4.0/

\begin{abstract}
There is a multitude of country studies between 2000-2018 that focus upon the relationship between corporate governance and profitability, with mixed results because studies have generally focused upon historic book value ratio measures of profitability such as Return on Assets (ROA) and Return on Equity (ROE), rather than based on market values. Thus, the purpose of this paper is to examine the effect of macro governance environments upon aggregate dividend yield and earnings per share for developed and emerging stock markets as measures of profitability and to provide a useful methodology for correctly incorporating risk measures in a more controlled manner than many current papers undertake. Using an augmented version of the dividend growth model and allowing for the control of risk factors, we find that macro governance environments have a significant influence upon dividend yield and earnings per share. The results have policy implications for government policy setters as improvements to governance environments may induce portfolio equity inflow, which is increasingly seen as a driving force for economic growth. Future research papers should use our methodology to better model firm profitability and corporate governance within a market value context and recognise the limitations of ROE and ROA as they rely upon less relevant book market values. Further, studies need to better capture interaction effects between macro (country-specific) and micro (firm-specific) governance.
\end{abstract}

\section{Keywords}

Macro-Governance, Profitability, Dividend Yield, Earning-Price Ratio

\section{Introduction}

The profitability of companies is often measured by accounting-based perfor- 
mance measures such as the dividend yield and earnings-price ratio. This profitability corresponds with the return shareholders require to invest in the company. Dividend yields are a measure of the profits paid out to investors as a proportion of the share price. They are an assessment of the ability of firms to distribute returns to shareholders. Dividend yields are a function of both the overall profitability of firms and their own internal payout ratio policies. Bekaert and Harvey [1] and Errunza and Miller [2] rely on the dividend yield as a measure of the return on equity. Under the outcome agency model of dividend payments by La Porta, Lopez-de-Silanes, Shleifer and Vishny [3], henceforth LLSV, countries with better investor protections should have higher dividend yields. If the quality of governance reflects the degree of investor protection, then it would be expected that countries that rate highly on governance would have better dividend payments made to shareholders. However, recent studies on the micro relationship of corporate governance and profitability have been mixed in terms of the significance and direction [4]. In this paper we take a macro approach to governance as encouraged by Kumar and Zattoni [5].

The earnings-price ratio is also a fundamental performance valuation ratio that indicates the amount of return; a shareholder would expect to receive for each dollar of investment. This measure is independent of firm-specific payout ratios and captures the total return to shareholders from both dividend payments and capital gains on their equity holdings. Earnings can be affected by the quality of governance in the same way as the return on equity in the preceding analysis. The earnings of a firm will increase when the quality of governance reduces both transaction costs and agency costs. This two-fold effect would increase the profitability of firms.

Patel, Balic \& Bwakira [6] reveal that there is an equity premium on firms with lower levels of information asymmetry. Klapper and Love [7] find a high degree of correlation between firm-level corporate governance and countries with good effective legal systems. The implication from these studies is that although earnings could be higher in better governance environments, the price of equity could also trade at a premium because of the stronger investor protections offered. The earnings-price ratio could therefore be positively or negatively impacted by governance according to whether earnings or price of equity is more affected.

\section{Literature Review}

The early literature on governance focused on firm-level agency costs arising from the ownership and control delineation structure of firms. The seminal work of Jensen and Meckling [8] provided the conceptual framework for such studies to develop. As the research progressed in this field, it was discovered that the corporate governance mechanisms themselves were subject to varying interpretations and weak levels of enforceability, and that the level of investor protection for which such mechanisms were designed to promote could deteriorate in 
the face of structurally flawless governance provisions. Indeed, the strength of such mechanisms rested solely on their ability to be adhered to by the firm. Thus, the enforceability of contractual provisions became the first extension in the greater understanding of the agency conflict between managers and shareholders.

The more recent literature (see e.g. [3] [9] [10] [11] [12] [13]) shifted the focus from firm-specific corporate governance to country-level governance environments. It was conjectured that ultimately the only way to enforce contracts between managers and shareholders was through legal action of some kind. The enforceability of contractual mechanisms underlying corporate governance was shown to be determined by the strength and efficiency of a country's judiciary. The focus of this literature review will be on this latest area of study which deals with the ability of institutions to impact on the profitability of firms.

Johnson [14] argues that there is no way to adequately protect investors except through strong domestic laws and an effective legal system. In a series of articles dealing with the legal foundations of countries, LLSV [3] [11] [12] originated the idea of the enforceability as well as the provision of corporate governance mechanisms in enhancing investor protection. Using a sample of 49 countries, LLSV [12] found that countries whose legal rules originate in the Common law tradition tend to protect investors considerably better than do the countries whose laws originate in the Civil law tradition.

Ball, Kothari \& Robin [9] examine the effect of legal factors on the properties of accounting earnings. They show that Common law accounting income exhibits significantly greater timeliness than Civil law accounting income. Accounting timeliness results in faster monitoring actions by security analysts, makes leverage and dividend restrictions binding more quickly, and affects the bonuses paid out to employees and managers. They argue that early incorporation of economic losses, as distinct from gradual incorporation over time, increases managers' incentives to attend to the sources of losses more quickly. Accounting systems which allow economic losses to be reflected in accounting income gradually over time also make manager statements less credible due to over-optimism. Conservative Common law accounting thus facilitates monitoring of managers and is an important firm-level corporate governance. That study [9] concludes that Common law disclosure standards reduce the agency costs of monitoring managers.

Bushman, Piotroski \& Smith [15] show that governance and financial transparency are related to judicial and political regimes. Governance transparency which is defined as the availability of information to those outside publicly traded firms, is highest in Common law countries. Financial transparency which captures the intensity and timeliness of financial disclosures and their interpretation and dissemination by analysts and the media, is higher in countries with low state ownership of enterprises, low state ownership of banks, and low risk of state expropriation of firms' wealth.

Dividend payout policy can be reflective of the ability of minority sharehold- 
ers to utilize their legal rights. LLSV [3] use a sample of firms from 33 countries around the world to examine dividend policies of large corporations. They take advantage of different legal protection of minority shareholders across different regimes to compare dividend policies of companies whose minority shareholders face different risks of expropriation of their wealth by corporate insiders. LLSV [3] distinguish between two alternative models of dividend payments. In the first model, dividends are an outcome of effective legal protection of shareholders, which enables minority shareholders to extract dividend payments from corporate insiders. In the second, dividends are a substitute for effective legal protection, which enables firms in unprotective legal environments to establish reputations for treatment of investors through higher dividend payout policies. Their results suggest that the agency approach is highly relevant to an understanding of corporate dividend policies around the world as they find consistent support for the outcome agency model of dividends. Firms operating in countries with better protection of minority shareholders pay higher dividends.

Dittmar, Mahrt-Smith \& Servaes [16] report that firms in countries with strong legal protection are less likely to maintain excess cash balances. The amount of free-cash flow is a known source of agency costs and should be limited to prevent managerial expropriation. They reject the possibility that their results are driven by the difficulty of raising needed external capital for firms in countries where investor protection is weak. Thus, the agency costs associated with free cash flow appear to be lower in countries with stronger investor protections.

Firms in strong investor protections should be valued higher due to better enforced shareholder rights. LLSV [17] examine the consequences of corporate ownership for firm valuation in different legal regimes. Their results suggest that poor shareholder protection is penalized with lower valuations and that higher cash-flow ownership by the controlling shareholder improves valuation, especially in countries with poor investor protection. Their empirical evidence supports the importance of the law in limiting expropriation of minority shareholders by controlling shareholders.

The results obtained by LLSV [17] have been criticised on similar grounds as their previous work since they do not factor into their estimations the interaction of risk variables. If, for example, countries with better protection of shareholder rights are also safer investment havens for an international asset manager, then companies in those countries would fetch higher valuations irrespective of agency problems.

Klapper and Love [7] show that good governance is highly correlated with better operating performance and market valuation. Better firm-level corporate governance is associated with higher operating performance and higher Tobin's-Q (market-value/book-value). Consistent with LLSV [17], Klapper and Love [7] find that firms rate higher on corporate governance in countries with good overall legal systems. Their results of governance indicate that the judicial 
environment is a significant factor in affecting firm-level corporate governance. An interesting result of their study is that firm-level corporate governance matters more towards firm valuation in counties with weak legal systems than those with well-developed legal institutions. This finding has strong policy implications and suggests that recommending to firms to adopt good governance practices is even more important in countries with poor judicial environments.

These results can be compared to the theoretical findings of Shleifer and Wolfenson [13] who argue that firms are unable to completely replicate a good legal environment on their own, but must depend on a supporting efficient judicial system. Firms can independently improve their investor protection and minority shareholder rights, to a certain degree, but that this adjustment mechanism is a second-best solution and does not fully substitute for the absence of a good legal infrastructure.

Patel, Balic \& Bwakira [6] analyse transparency and disclosure scores in 19 emerging markets for 354 firms. They find that firms with higher transparency and disclosure are valued higher than comparable firms with lower transparency and disclosure, consistent with the notion that the market places a premium on companies with lower asymmetric information problems. Higher transparency and better disclosure reduce the information asymmetry between a firm's management and financial stakeholders, mitigating the agency problem in corporate governance. The authors further find that the Asian emerging markets and South Africa have significantly higher levels of transparency and disclosure compared to the Latin American, Eastern European and Middle Eastern emerging markets. The results show that the Asian emerging markets exhibit greater transparency and disclosure following the recent currency, banking and equity market crisis. They suggest that market opening is positively correlated with transparency and disclosure. However, the results obtained under that study are to be treated cautiously since the authors use bi-variate correlations with no use of control variables.

Rjan and Zingales [18] argue that firms and industries that are more dependent on external finance tend to grow faster in countries where financial markets are better developed, and test this prediction on a large panel of industry-level cross-country data. Carlin and Mayer [19] build on the Patel, Balic \& Bwakira [6] approach to probe further into the relationships between industrial activity, financial systems and legal arrangements, and conclude that the legal protection of investors is correlated with the growth of equity-financed industries. Better legal environments reduce the cost of external financing which fosters firm growth.

Demirguc-Kunt and Maksimovic [20] investigated whether differences in financial systems and legal institutions constrain firms to grow at rates no greater than those they could attain by relying on their internal resources of short-term borrowing. They estimate the maximum growth rate that each firm of their sample could attain without access to long-term financing, and compare these 
potential growth rates to those attained by firms in countries with different legal and financial systems. They show that in countries with better legal systems, more active stock markets and larger banking sectors, a greater fraction of firms fund growth by external long-term finance. Thus, active stock markets and well-developed legal systems are important factors in facilitating firm growth. The evidence indicates that firms in countries that have active stock markets and high ratings for compliance with legal norms can obtain external funds and grow faster.

Most studies reflect on the constructive outcomes of institutional development on economic stability. Improving the level of investor protection and reducing the degree of aggregate agency costs through the process of institutional change has become a major concern. However, the way this institutional evolution will occur across international markets is a disputed topic throughout the literature.

Lombardo and Pagano [21] [22] argue that the profitability on projects is increasing in the efficiency of legal institutions. A reduction in the resources needed to enforce breached contracts expands the production opportunity set of companies and thereby their profitability. These arguments are supported by the findings of Bhattacharya and Daouk [23] and Hail and Leuz [24] that legal institutions can lower the cost of capital to firms.

Demirguc-Kunt and Maksimovic [20] report that the return on assets of the firms in their sample is negatively correlated with the same rule-of-law indicator used by Lombardo and Pagano [22], after controlling for various country-specific macroeconomic variables such as inflation, deposit bank assets and stock market capitalization divided by GDP. These studies suggest that the supply side of equity finance is more affected by legal development. The contradiction between the two studies, apart from the different measures of profitability and data used, may be due to the fact Demirguc-Kunt and Maksimovic [20] fail to control for global risk factors in their regressions.

At the centre of traditional skepticism about government regulation is the Coase [25] theorem. The theorem states that when transaction costs are zero, market participants will organize their transactions in ways that achieve the most efficient outcomes. When they can do so, it is not necessary for the government to engage in corrective actions through taxes, regulations, or even legal rules. Under the Coase theorem the quality of institutions would be an irrelevant factor on the profitability of the firm, as their involvement in the market is deemed unnecessary.

The theoretical literature on market failures, externalities and information asymmetry has demonstrated that institutions have an important role within the market (see for e.g. [25] [26]). Coase [27] contends that without considering transaction costs it is impossible to understand properly the working of the economic system and have a sound basis for establishing economic policy. In order to carry out any market transaction it is necessary to discover the parties of trade, to conduct negotiations leading up to a bargain, to draw up the contract, 
and to undertake the inspection needed to make sure that the terms of the contract are being observed.

Transaction costs are associated to searching for market participants, bargaining, decision making, creation and enforcing of contracts. They are the costs that arise when individuals exchange ownership rights to economic assets and enforce their exclusive rights. Wallis and North [28] demonstrated in an empirical study that $45 \%$ of the United States gross national product is devoted to the transaction sector in 1970. Transactions are not governed by the price system and therefore institutional organizations are required to oversee their proper functioning. The quality of governance is a proxy for the ability of regulators to effectively monitor transaction costs.

The well-documented agency costs between the firm's managers and shareholders reduce the overall return on equity. The quality of the legal environment or more generally, the efficiency of regulatory institutions will impact on the occurrence of managerial expropriation which will increase the returns to shareholders. This is the line of thought in the early studies dealing with law and finance [11]. An extension of this is to consider that the profitability of a firm is a function of the sum of the profitability of each $\mathrm{N}$ individual investment projects available to it. The traditional investment decision rule is to invest into those projects which have positive net present values (NPV). This profitability is a function of the transaction costs that arise between the firm and parties it must contract and deal with. These include employees and other corporate entities. The operational functioning of business activities requires the use of sophisticated transactions among economic agents. Employees need to be paid through developed banking networks, contractual arrangements need to be enforced between parties, and a medium of exchange needs to be in place ${ }^{1}$. These transaction costs are influenced by quality of the institutions that are empowered to regulate them. The profitability of each project is therefore a function of the quality of governance. Where the quality of institutions reduces the costs associated to transacting, the profitable project opportunity set available to firms will expand.

Each project also has a set of externalities or side effect costs that spill over onto those not involved in the business enterprise. In a state of zero transaction costs, the firm and the participants who are affected by the activities of each project will contract between themselves to achieve the most efficient allocation of resources. In this laissez faire economy the profitability of each project is maximized. However, the negotiations between the firms and those involved in the operations of each project are costly in the presence of transaction costs. The creation of contracts and the process of dispute resolution are costs which reduce the overall profitability or NPV of each project available to the firm. When the set of positive NPV projects available to firms expands, the demand for eq${ }^{1}$ Taxes are also a known source of interaction between firms and government institutions, and may even be construed as transaction costs themselves; however this avenue of research is not examined in this paper. 
uity finance should increase, resulting in increased returns to current shareholders (according to the theoretical model discussed earlier).

The model proposed by Lombardo and Pagano [22] related only legal factors in reducing both the agency cost of firms and the profitability of the project set available for investment. The quality of the legal environment is a sub-set of the governance system. The effectiveness of the regulatory and political institutions that govern a country invariably influence the protections afforded to investors and the costs associated to transacting in the market. Lower levels of corruption and higher degrees of transparency and accountability influence the returns on all project investments in an economy through lower costs of transacting.

\section{Data Sources}

\subsection{Stock Market Returns and Accounting Ratios Data}

This study incorporates a total sample of 50 developed and emerging stock markets, sourced from the Morgan Stanley Capital International (MSCI) stock market index database. The MSCI index series is value weighted and corrected for dividend payments and capitalization changes. Each index covers approximately $85 \%$ of the free float-adjusted market capitalization in the country or region the index represents. The MSCI indices are used widely in practice and theory as they are broadly representative of each country's market composition to investors. The monthly equity returns, are selected from January 1995 to December 2002. In 2002, The Sarbanes-Oxley Act (SOX) has been signed into law in the United States of America. This act has been introduced largely due to the corporate scandals in early 2000s. SOX-type regulations were subsequently enacted in other countries, such as Canada, India, Japan and many European countries. We argue that the corporate governance measurements have been significantly changed after 2002. Therefore, our sample only focused on the pre-SOX period and leaving the transition period after 2002 for future study. In addition, this study uses the MSCI World Index which is US dollar value weighted and regarded to be one of the best proxies for the world market portfolio.

Data on valuation ratios such as price-earnings ratios and the dividend yield on the index are available for the same countries on MSCI indices through DataStream. These are obtained for each stock index on an annual basis. The price-earnings series is defined as the "weighted average price/earnings ratio based on 12-month forward earnings". The dividend yield is defined as "weighted dividend yield based on the indicated annual dividend". The yield on domestic 10 -year government bonds is obtained from DataStream for a sample of $22 \mathrm{de}$ veloped countries as the local 10-year DataStream benchmark bonds.

\subsection{Governance Data}

Governance data is sourced from Kaufmann, Kraay \& Mastruzzi [29] who compiled governance indicators using principal component analysis based on several hundred individual variables measuring perceptions of governance, drawn from 
25 separate data sources constructed by 18 different organizations. The data is available for 200 countries. The principal component analysis resulted in the establishment of 6 dimensions. These six dimensions of governance cover the years 1996, 1998, 2000 and 2002 and represent "Voice and Accountability" (VA), "Political Stability and Absence of Violence" (PS), "Government effectiveness" (GE), "Regulatory Quality" (RQ), "Rule of Law" (RL) and "Control of Corruption" (CC). Thus, Kaufmann et al capture the quality of a country's institutional environment ${ }^{2}$. Their study is the most comprehensive study ever undertaken and represents a landmark breakthrough in international governance research.

\section{Methodology}

The model used to test the impact of the quality of governance on accounting-based measures of performance is adapted from Lombardo and Pagano [22]. An augmented Gordon model [30] of security valuation was used to model cross-country dispersion of the return on equity to international differences in legal environments. This study replaces the legal variables used in their study with governance indicators. A brief summary of their model is presented here with the relevant modifications.

The Gordon model [30] determines the intrinsic value of a stock or index based on a future series of dividends that grow at a constant rate. It assumes a dividend per share is payable in one year and its annual value grows in perpetuity at a constant rate. The model calculates the security's current value as the present value of the infinite series of future dividends. Under general assumptions, the stock market index in country $i$ at time $t$, is the expected value of discounted dividends in perpetuity from the component stocks:

$$
P_{i, t}=E_{t}\left[\sum_{j=1}^{\infty} \frac{D_{i, t+j}}{\left(1+k_{i, t+j}\right)^{j}}\right], t=1, \cdots, T ; i=1, \cdots, N
$$

where $E_{t}$ is the expectation conditional on information known at time $t, D_{i, t+j}$ is the dividend paid out by the companies listed in country $i$ at time $t+j$, and $k_{i, t+j}$ is the per-period risk-adjusted discount factor between time $t$ and $t+j$ relevant for the stream of dividends from country $i$. A simple version of the Gordon model assumes $k_{i}$ to be constant and $E_{t}\left(\left|D_{i, t+j}\right|\right)=D_{i, t}\left(1+g_{i}^{D}\right)^{j}$, where $D_{i, t}$ is the current dividend and $g_{i}^{D}$ is a constant dividend growth rate specific to country $i$. Under these assumptions, the expected dividend yield becomes:

$$
\frac{D_{i, t}}{P_{i, t}}=D Y_{i, t}=k_{i}-g_{i}^{D}, t=1, \cdots, T ; i=1, \cdots, N
$$

To calculate the risk-adjusted required rate of return $k_{i}$, a model of the equilibrium determination of the rates of return on stocks with different risk characteristics is required. In an international CAPM framework, the systematic risk of

${ }^{2}$ These variables are clustered in Table 1 to represent 3 major subdivisions of macro-governance environments. 
stock market index $i$, is only due to its covariance with the world market [31]. When the required rate of return on equities also depends on the governance variables, $k_{i}$ may be written as:

$$
k_{i}=f_{i}\left(\beta_{i}\right)+\gamma \rho_{i}\left(G_{i}\right), i=1, \cdots, N
$$

where $\beta_{i}$ is the country's vector of betas with the relevant risk factors (Figure 1 outlines what these risk factors are and sources) and $G_{i}$ are the governance indicators. When the international CAPM holds, $f_{i}\left(\beta_{i}\right)=\alpha I R_{i}+\lambda \beta_{i}^{w}$ where $\lambda$ is the market price for risk attached to the world beta $\beta_{i}^{w}, I R_{i}$ is the yield on a long-term risk-freedomestic security in country $i, \gamma=0$ and the required rate of return $k_{i}$ in a market is equivalent to $f_{i}\left(\beta_{i}\right)$. Lombardo and Pagano [22] suggest the use of nominal domestic interest rates, since different dividend yields across countries must be allowed to reflect different expected inflation rates. Assuming that the coefficients on the market risk and the governance indicator are constant, the required return on equity in a cross-sectional analysis can be written as:

$$
k_{i}=\alpha I R_{i}+\lambda \beta_{i}^{w}+\gamma G_{i}, \quad i=1, \cdots, N
$$

Imposing this linear specification for the risk premium component of the return on equity in Equation (3), the following result is obtained:

$$
D Y_{i}=\alpha I R_{i}+\lambda \beta_{i}^{\omega}+\gamma G_{i}+\delta g_{i}^{D}+\varepsilon_{i}, \quad i=1, \cdots, N
$$

where the restriction $\delta=-1$ should hold if this simple version of Gordon's model were correct. Unfortunately, data on the expected growth in dividends on country stock indices are difficult to obtain. Bekaert and Harvey [1] argue that dividend yields can be considered stationary random variables. This motivates the use of a measure of expected dividend growth based on the percentage increase in the dividends ${ }^{3}$ over the preceding twelve months. This is estimated as:

WRDRET: continuous return US dollar return of the MSCI world equity market in excess of the one-month US treasury bill rate. Source: MSCI Data available through DataStream.

G10FX: $\log$ first difference in the weighted average of the foreign exchange value for the US dollar against a subset of the broad index currencies that circulate widely outside the country of issue. Source: Federal Reserve Bank of St. Louis

G7UI: unexpected component of monthly global inflation, derived from an ARIMA model applied to the log difference of the G7 weighted CPI's, using the shares of the total real gross domestic product. Source: DataStream $($ mnemonic $=$ G7OCP009F).

OIL: change in the monthly average OPEC oil basket price in US dollars. Source: DataStream $($ mnemonic $=$ OILOPEC $)$.

G7IP: weighted average of industrial production growth rates in the G7 countries where a measure of relative production shares is used as the weights. Source: DataStream $($ mnemonic $=$ G7OPR035GI).

Figure 1. Description of global risk factors.

${ }^{3}$ Dividends paid out on each country index at time $t$ are determined by multiplying the dividend yield data by the price index for each country. This can be written as $D=D Y \times P I$ where $P I$ is the price of the index at time $t$. 


$$
g_{i}^{D}=\ln \left(\frac{D_{i, t}}{D_{i, t-1}}\right), i=1, \cdots, N
$$

where $D_{i}$ represents the dividend payment on the country index for country $i$.

Estimates for $\beta_{i}^{w}$ are obtained by a first-stage regression of the market $i$ excess return on the MSCI World excess return as follows:

$$
\left[\begin{array}{c}
r_{1, t}-r_{t}^{f}=\alpha_{1}+\beta_{1}^{w}\left(r_{t}^{w}-r_{t}^{f}\right)+\varepsilon_{1, t} \\
\vdots \\
r_{50, t}-r_{t}^{f}=\alpha_{50}+\beta_{50}^{w}\left(r_{t}^{w}-r_{t}^{f}\right)+\varepsilon_{50, t}
\end{array}\right], t=1, \cdots, T
$$

The $\beta_{i}^{w}$ estimates are obtained using 24 months of MSCI stock index returns data for each of the periods 1995-96, 1997-98, 1999-2000 and 2001-2002. This produces four sets of world beta estimates for each $I^{\text {th }}$ country. The possibility of cross-market correlation for the errors, $\varepsilon_{i, t}$ is allowed and the estimates obtained through seemingly unrelated regression (SUR) method.

Since differences in tax treatment of dividends across countries may affect payout ratios, a measure of the relative stance of the tax system towards different uses of earnings is used as a separate regressor in the model. The variable "Dividend Tax Preference" (DTP) is drawn from [3]. This variable is defined as the ratio of the net-of-taxes value to outside shareholders of one dollar in earnings distributed out as dividends to the net-of-taxes value of one dollar of earnings retained in the firm. It is intended to capture the extent of tax disadvantage borne by dividends relative to capital gains.

Equation (5) can also be used to derive a specification involving the earnings-price ratio. If it is assumed that dividends are a common fraction of earnings in all countries, $D=b(1-t) E$ and the payout ratio $b$, and taxes $t$, are assumed to be constant for each country. It follows that $D \propto E$ and that the same risk factors can be used in an estimation where earnings-price ratio is treated as the dependent variable. Another testable specification involving the earnings-price ratios $(E P)$ is described as:

$$
E P_{i}=\alpha^{\prime} I R_{i}+\lambda^{\prime} \beta_{i}^{w}+\gamma^{\prime} G_{i}+\delta^{\prime} g_{i}^{E}+\varepsilon_{i}^{\prime}, i=1, \cdots, N
$$

where the superscript primes indicate that the coefficients in Equation (8) may differ from the analogous coefficients in Equation (5). The expected growth in earnings is measured by the growth in earnings ${ }^{4}\left(g_{i}^{E}\right)$ over the preceding 12 months:

$$
g_{i}^{E}=\ln \left(\frac{E_{i, t}}{E_{i, t-1}}\right), i=1, \cdots, N
$$

The implicit assumption again is that the actual growth in the preceding 12 months is an appropriate measure of expected growth in earnings for the following 12 months Since the estimated world beta variable has measurement errors, instrumental variables are used to avoid inconsistent regression estimates ${ }^{4}$ To obtain the earnings for time $t$, the earning-price ratio for country $i$ is multiplied by the price index at $t$. This can be written as $E=E P \times P I$ where $P I$ is the price of the index. 
of the model parameters ${ }^{5}$. All the variables in the regression estimates where governance appears as a regressor are weighted by the standard errors of the governance point estimates ${ }^{6}$ to obtain the following equations:

$$
\begin{aligned}
D Y_{i} / \sigma_{G, i}= & \psi+\gamma\left(G_{i} / \sigma_{G, i}\right)+\alpha\left(I R_{i} / \sigma_{G, i}\right)+\lambda\left(\hat{\beta}_{i}^{w} / \sigma_{G, i}\right) \\
& +\delta\left(g_{i}^{D} / \sigma_{G, i}\right)+\chi\left(D T P_{i} / \sigma_{G, i}\right)+\varepsilon_{i}, i=1, \cdots, N \\
E P_{i} / \sigma_{G, i}= & \psi^{\prime}+\gamma^{\prime}\left(G_{i} / \sigma_{G, i}\right)+\alpha^{\prime}\left(I R_{i} / \sigma_{G, i}\right)+\lambda^{\prime}\left(\hat{\beta}_{i}^{w} / \sigma_{G, i}\right) \\
& +\delta^{\prime}\left(g_{i} / \sigma_{G, i}\right)+\varepsilon_{i}^{\prime}, \quad i=1, \cdots, N
\end{aligned}
$$

The previous sample of 50 countries is reduced to 22 primarily developed countries in this analysis due to data restrictions ${ }^{7}$. Using CIA World Factbook [32] the sample of countries can further be divided into those of Common law origins and those of Civil law descent. The sample of 22 countries contains 14 markets which are considered to have Civil law legal systems and 8 countries classified with Common law legal systems. Balanced panel regressions are used to combine the cross-sectional regressions over the years 1996, 1998, 2000 and 2002, which again allows for complete use of all governance information.

\section{Results on Dividend Yields}

LLSV [3] find that effective legal systems are correlated with higher dividend payments. The legal system is a sub-set of the governance environment, and so it is expected that countries that rate highly on governance are positively associated with larger dividend yields payments. It is also expected the $I R$ and $D T P$ variables to yield positive coefficients. Higher nominal interest rates and tax regimes supportive of higher dividend payouts should be positively associated with larger dividend yields. According to the Gordon model, the expected growth in dividends should have a coefficient of -1 , however since all variables are divided by the standard errors of the governance observation, only a negative sign on the coefficient should be found.

The empirical results for dividend yields are reported in Table 1. Panel $A$ presents the regression results for the theoretical specification of the dividend yield model (Equation (10)). Column 1 reports the results obtained from the baseline regression of the model $(B 1)$. Consistent with expectations, positive and significant coefficients are found on the domestic government bond yield (IR) and the $D T P$ variables. The coefficient of the expected growth in dividends variable is however not negative, as theory would suggest, but marginally positive although it is insignificant in all specifications except where RL is introduced as a regressor. The signs of the coefficients are comparable across all regressions although $D T P$ becomes statistically insignificant with the introduction of the ${ }^{5}$ The one-month lag world beta estimate $\left(\beta_{t-1}^{w} / \sigma_{G}\right)$ is used as the instrument.

${ }^{6}$ This procedure places greater weights on governance observations with greater precision in estimation.

${ }^{7}$ The proxies for local interest rates were the Data Stream Benchmark Bonds which are only available for 22 countries from the original sample of 50 countries. 
governance variables. The adjusted R-square of the first baseline model is $24.88 \%$.

Columns 2-7 report the regression results where the governance indicators are included as explanatory variables. After controlling for undiversifiable risk and adjusting the accounting measures for differences in expected inflation and growth prospects, the governance indicators play an important role in explaining the cross-sectional behaviour of dividend yields.

Under Panel $A$, all measures of governance are found to be significant and positively associated with dividend yields, except the RL indicator that does not have a significant coefficient.

Table 1. Dividend yields.

This table presents the balanced panel regression results where the dependent variable is the dividend yield on an index. Panel $A$ reports the theoretical specification of the model and Panel B presents the model with the use of legal origins dummies. $D 1$ has a value of 1 if a country is of Common law origins and 0 if its origins are Civil law. $D 2$ has a value of 1 if a country has Civil law origins and 0 if it is Common law. Column 1 presents the baseline specification and columns $2-7$ present the results where each of the governance indicators has been introduced individually into the first baseline model $(B 1)$. The governance indicators are further classified according to the governance cluster they are constituents of, with three distinct clusters reported. Instrumental variables are used to control for the effects of measurement errors in the first stage estimation of world betas using SUR. Columns 8 - 11 present the results for the adjusted specification with the Civil law (D1) and Common law (D2) dummy variables. All regressors are divided by the standard error of the governance point estimates. $P$-values are reported in parentheses.

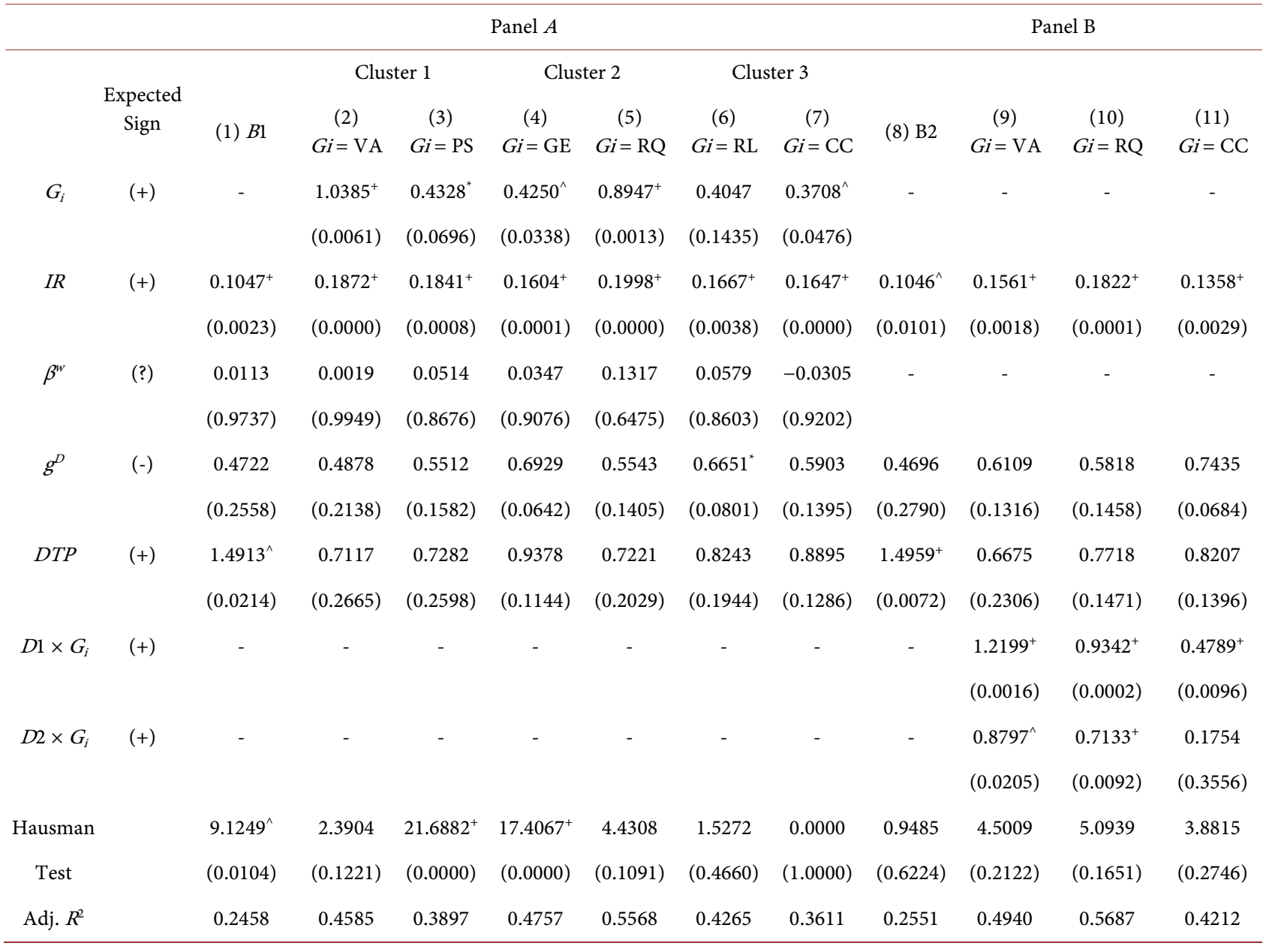

*, ^, ${ }^{+}$indicate significance at the $10 \%, 5 \%$ and $1 \%$ levels respectively. 
Under Panel $B$ the theoretical model is modified to study the effects of legal origins on the results. LLSV [12] have shown Common law countries have superior investor protection when compared to Civil law countries. To explore the impact of governance in varying legal environments two dummy variables are multiplied by the governance indicators and introduced separately into the model. The first dummy $D 1$ has a value of 1 if the country is a Common law country and a value of 0 if the country is of Civil law origins. The second dummy variable $D 2$ has a value of 1 if a country is of Civil law descent and a value of 0 if it is Common law. The original governance indicators are removed from the analysis. The world beta variable is also removed due to its lack of statistical significance in Panel $A$ regressions.

Models with the highest coefficient significance on the governance indicators for each cluster from Panel $A$ are used to test the alternate specifications under Panel $B$. The models tested under Panel $B$ are where VA, RQ and CC appear as regressors, along with baseline specification $(B 2)$ attributed to the alternate model.

The results under Panel $B$ indicate that the quality of governance has a positive impact on dividend yields in both Civil law and Common law countries. The coefficients of both the dummy-governance variables are significant at the $1 \%$ level where RQ is introduced as the measure of governance. A similar result is applicable where VA is introduced, however under column 11 where CC is introduced as a governance measure, the impact of governance is statistically significant in Common law countries only.

\section{Results on Earning-Price Ratio}

Expectations on the sign of the coefficients on the governance indicators for the earnings-price ratio are unclear. Although better quality governance can reduce transaction costs and hence increase the earnings of firms, higher equity prices resulting from superior investor protection environments could offset the effect on the earnings-price ratio. Where there is a premium attached to equity in good institutional environments (see [11]), the change in the earnings-price ratio across varying governance regimes will be uncertain.

It is expected that a positive sign for the coefficient of the domestic government bond yield $(I R)$ should occur since higher domestic interest rates should increase the return on equity. Similar to the reasoning under the dividend yield section, if the augmented Gordon model were to hold, a negative coefficient should result on the expected growth in earnings variable.

Table 2 reports the regression results of Equation (11). The baseline specification is described under column 1 with columns $2-7$ reporting the regression results where governance is included as a regressor under the relevant clusters ${ }^{8}$.

${ }^{8}$ To interpret the results, it should be noted that the dependent variable averages 19.19 in the sample, has a standard deviation of 9.99 and a range between 9.30 and 66.70 and that all the regressors are divided by the standard errors of the governance estimates. 
The domestic bond yield $(I R)$ and the expected growth in earnings $\left(g^{E}\right)$ are found to have coefficients whose signs are in line with expectations. The world beta variable $\beta^{w}$, does not appear significant in any of the Panel $A$ specifications.

Under Panel $A$, the coefficient of the VA indicator is positive and significant at the $5 \%$ level. All coefficients attached to governance indicators are positive, although only the coefficient of VA is measured accurately. The adjusted R-squares range between $54.71 \%$ and $63.96 \%$ where governance indicators have been included and $44.02 \%$ for the control regression.

The results indicate that the quality of governance positively affects the profitability of firms, by reducing both transaction costs as defined by Coase, and agency costs. The reduction in transaction costs increases the demand for equity

Table 2. Earnings-price ratio.

This table presents the balanced panel regression results where the dependent variable is the earnings-price ratio. Panel $A$ reports the theoretical specification of the model and Panel B presents the model with the use of legal origins dummies. $D 1$ has a value of 1 if a country is of Common law origins and 0 if its origins are Civil law. $D 2$ has a value of 1 if a country has Civil law origins and 0 if it is Common law. Column 1 presents the baseline specification and columns 2 - 7 present the results where each of the governance indicators has been introduced individually into the first baseline model $(B 1)$. The governance indicators are further classified according to the governance cluster they are constituents of, with three distinct clusters reported. Instrumental variables are used to control for the effects of measurement errors in the first stage estimation of world betas using SUR. Columns $8-11$ present the results for the adjusted specification with the Civil law $(D 1)$ and Common law $(D 2)$ dummies introduced into the estimations. All regressors are divided by the standard error of the governance point estimates. P-values of the coefficients are reported in parentheses.

\begin{tabular}{|c|c|c|c|c|c|c|c|c|c|c|c|c|}
\hline & & & & & Panel $A$ & & & & & Pan & el B & \\
\hline & & & Clus & ter 1 & Clus & ter 2 & Clus & er 3 & & & & \\
\hline & Expected & & & & & & & & & & & \\
\hline & Sign & (1) $B 1$ & $\begin{array}{c}(2) \\
G i=\mathrm{VA}\end{array}$ & $G i=$ PS & $G i=\mathrm{GE}$ & $G i=\mathrm{RQ}$ & $G i=\mathrm{RL}$ & $G i=\mathrm{CC}$ & (8) B2 & $\begin{array}{c}\text { (9) } \\
G i=\mathrm{VA}\end{array}$ & $\begin{array}{c}(10) \\
G \dot{j}=\mathrm{RO}\end{array}$ & $G i=\mathrm{CC}$ \\
\hline$G_{i}$ & (?) & & $0.0165^{\wedge}$ & 0.0076 & 0.0050 & 0.0053 & 0.0087 & 0.0045 & - & - & - & - \\
\hline & & & $(0.0753)$ & $(0.2776)$ & $(0.3327)$ & $(0.4433)$ & $(0.1617)$ & $(0.2404)$ & & & & \\
\hline$I R$ & $(+)$ & $0.0034^{+}$ & $0.0046^{+}$ & $0.0049^{+}$ & $0.0043^{+}$ & $0.0041^{+}$ & $0.0048^{+}$ & $0.0044^{+}$ & $0.0034^{+}$ & $0.0053^{+}$ & $0.0051^{+}$ & $0.0057^{+}$ \\
\hline & & $(0.0000)$ & $(0.0000)$ & $(0.0006)$ & $(0.0000)$ & $(0.0000)$ & $(0.0001)$ & $(0.0000)$ & $(0.0000)$ & $(0.0000)$ & $(0.0000)$ & $(0.0000)$ \\
\hline$\beta^{w}$ & (?) & 0.0022 & 0.0037 & 0.0045 & 0.0064 & 0.0065 & 0.0048 & 0.0033 & - & - & - & - \\
\hline & & $(0.6985)$ & $(0.4632)$ & $(0.4207)$ & $(0.2707)$ & $(0.2563)$ & $(0.4041)$ & $(0.5458)$ & & & & \\
\hline$g^{E}$ & $(-)$ & $-0.0313^{+}$ & $-0.0341^{+}$ & $-0.0321^{+}$ & $-0.0347^{+}$ & $-0.0330^{+}$ & $-0.0347^{+}$ & $-0.0330^{+}$ & $-0.0305^{+}$ & $-0.0327^{+}$ & $-0.0325^{+}$ & $-0.0332^{+}$ \\
\hline & & $(0.0001)$ & $(0.0001)$ & $(0.0001)$ & $(0.0001)$ & $(0.0007)$ & $(0.0001)$ & $(0.0002)$ & $(0.0001)$ & $(0.0001)$ & $(0.0000)$ & $(0.0000)$ \\
\hline$D 1 \times G_{i}$ & (?) & - & - & - & - & - & - & - & - & 0.0134 & 0.0035 & 0.0078 \\
\hline & & & & & & & & & & $(0.1471)$ & $(0.4918)$ & $(0.2003)$ \\
\hline$D 2 \times G_{i}$ & (?) & - & - & - & - & - & - & - & - & $0.0209^{\wedge}$ & $0.0103^{*}$ & $0.0142^{\wedge}$ \\
\hline & & & & & & & & & & $(0.0265)$ & $(0.0686)$ & $(0.0296)$ \\
\hline Hausman & & 0.6198 & 2.9680 & 0.2472 & 0.2572 & 2.0663 & 0.0193 & 0.1061 & 0.5448 & 0.4759 & 1.0822 & 0.7158 \\
\hline Test & & $(0.7335)$ & $(0.2267)$ & $(0.8837)$ & $(0.8793)$ & $(0.5588)$ & $(0.8895)$ & $(0.9483)$ & $(0.7616)$ & $(0.4903)$ & $(0.7814)$ & $(0.8695)$ \\
\hline Adj. $R^{2}$ & & 0.4402 & 0.6047 & 0.5609 & 0.6204 & 0.6396 & 0.5964 & 0.5471 & 0.4460 & 0.6393 & 0.6579 & 0.6353 \\
\hline
\end{tabular}

${ }^{*}, \wedge,{ }^{+}$indicate significance at the $10 \%, 5 \%$ and $1 \%$ levels respectively. 
and the overall return to shareholders. However, the effect of governance in increasing the supply of equity due to better investor protection is not as pronounced. The reduction in agency costs does not substantially compel investors to increase the supply of funding to firms resulting in an equity premium to firms operating in good governance countries. Thus, the results do not lend support for the supply centered view of the theoretical model. The profitability of firms is increasing in the quality of governance, but the impact on the supply of equity is not as prominent.

To explore the impact of legal origins on the results, Common and Civil law dummies $D 1$ and $D 2$ are again used under Panel $B$. The $\beta^{w}$ variable is also removed to provide the alternative specification of the model. The results indicate that the quality of governance is a significant explanatory variable in Civil law countries only. All the coefficients of the governance indicator multiplied by the $D 1$ dummy are insignificant, which implies that the quality of governance does not have a statistically significant impact on the earnings-price ratio on a country's stock index when it is of Common law descent.

The results obtained under Panel $B$ when interpreted in connection with the findings of LLSV [12], demonstrate that the importance of governance is more pronounced in environments with lower levels of investor protection. Governance appears to be a significant factor in explaining the cross-sectional differences in earnings-price ratio amongst Civil law countries which have lower levels of investor protection. Poor investor protection countries would have higher levels of agency costs, and thus the quality of governance through improved regulation and the enforcement of corporate governance mechanisms should have a positive impact on earnings.

Common law countries that have generally higher levels of investor protections and thus lower levels of agency costs are not as affected by improvements in the quality of governance. The earnings-price ratio is not significantly impacted on by the quality of governance in Common law countries. This could be explained by either higher equity prices in Common law countries due to premiums associated with better investor protections, or a reduced impact on transaction costs and agency costs. Klapper and Love [7] argue that corporate governance is even more important on firm valuation in countries with poor legal institutions. The results obtained from Panel $B$ indicate that the quality of governance is even more important in countries with poor investor protections and higher levels of agency costs than countries with better protected investors. Improving a country's governance rating is therefore even more important for Civil law countries that tend to have already low levels of investor protection than for Common law countries.

The results from Panel $B$ appear at odds with the earlier findings of the demand centered approach to the effects of governance. The earnings-price ratio of firms is not substantially influenced by the quality of governance in Common law countries, but is related in the case of Civil law countries. This implies that governance has an impact on the degree of agency costs, but not on the transac- 
tion costs inherent in firm operations. The demand centered approach under the theoretical model assumes an increase in the demand for equity financing arising from an enlargement of the profitable project opportunity set due to a reduction in transaction costs. Thus, it would be expected under this approach, that even though Common law countries have lower levels of aggregate agency costs (due to better legal systems), the quality of governance would still be a statistically significant factor in positively affecting the earnings-price ratio, through a reduction in transaction costs. The lack of statistical significance on the coefficients of the governance indicators that are multiplied by the Common law dummy $(D 1)$ can be explained by an equity premium attached to firms in Common law countries with higher levels of investor protections. Thus, although earnings are positively influenced by the quality of governance in Common law counties, equity prices trade at a premium, reducing the overall earnings-price ratio. The two effects cancel each other to reduce the statistical significance of governance indicators on the earnings-price ratio.

\section{Conclusions}

This study examined the impact of governance on the dividend yield and earnings-price ratio of country stock indices. Both the dividend yield and the earnings-price ratio are found to be positively associated with quality of governance in a country. The results for dividend yields confirm the outcome agency model of dividend payments LLSV [3]. When the quality of governance improves the level of investor protection, investors use their protected rights to extract dividends from firms. In the case of the earnings-price ratio, higher quality governance increases the profitability of firms by lowering transaction costs and agency costs. Assuming these accounting-based measures are representative of the return on equity, the results support the notion that the quality of governance is positively associated with returns to shareholders.

The significance of the quality of governance on the earnings-price ratio was found to be more pronounced in Civil law countries than Common law countries. This implies that the importance of institutions is more pronounced in weak investor protection environments than in countries with well-developed legal systems.

The quality of the institutional environment positively impacts on shareholder returns through reductions in transaction costs and agency costs. This two-fold effect increases the profitability of firms and the demand for equity finance. The empirical evidence suggests that institutional factors impact on the returns to shareholders.

We stress that our findings are based on market-based measures of performance unlike previous studies 2000-2018 that find mixed results for the relationship between firm performance and corporate governance because they tend to rely on book-based measures like ROA and ROE. This paper thus provides a coherent methodology to researchers wanting to investigate corporate governance and performance within a market value context. 
Based on the results, the practical research significance of this article is the finding that the use of market-based measures of performance would provide clearer empirical results than the use of book-based measures. Both the use of dividend yield and earnings-price ratio, which are market-based measures, yield empirical results that clearly support the need for better governance to achieve higher profitability. The findings also support the view that better quality of institutional governance would have more impact on profitability in environments with weak investor protection as compared to environments with strong investor protection.

Nevertheless, the finding of this article is limited by the confine of the data and methodology used. Further research may like to consider a dynamic model instead of a static model. A dynamic model would be more appropriate for the period after the year 2002 considering that individual economies could be in transition as new legislations to improved governance were introduced. That may also entail some modifications to the variables used that are necessary for a dynamic model. A more advanced econometric methodology would also be essential to estimate the dynamic model.

\section{Conflicts of Interest}

The authors declare no conflicts of interest regarding the publication of this paper.

\section{References}

[1] Bekaert, G. and Harvey, C. (2000) Foreign Speculators and Emerging Equity Markets. Journal of Finance, 55, 565-613.

https://onlinelibrary.wiley.com/doi/full/10.1111/0022-1082.00220 https://doi.org/10.1111/0022-1082.00220

[2] Errunza, V. and Miller, D. (2000) Market Segmentation and the Cost of Capital in International Equity Markets. Journal of Financial and Quantitative Analysis, 35, 577-600. https://www.jstor.org/stable/2676256?seq=1\#metadata_info_tab_contents https://doi.org/10.2307/2676256

[3] La Porta, R., Lopez-de-Silanes, F., Shleifer, A. and Vishny, R. (2000) Agency Problems and Dividend Policies around the World. Journal of Finance, 55, 1-33.

https://onlinelibrary.wiley.com/doi/10.1111/0022-1082.00199 https://doi.org/10.1111/0022-1082.00199

[4] Love, I. (2011) Corporate Governance and Performance around the World: What We Know and What We Don't. The World Bank Research Observer, 26, 32-70. https://elibrary.worldbank.org/doi/abs/10.1093/wbro/lkp030 https://doi.org/10.1093/wbro/lkp030

[5] Kumar, P. and Zattoni, A. (2013) How Much Do Country-Level or Firm-Level Variables Matter in Corporate Governance Studies? Editorial, Corporate Governance: An International Review, 21, 199-200. https://onlinelibrary.wiley.com/doi/full/10.1111/corg.12025 https://doi.org/10.1111/corg.12025

[6] Patel, S., Balic, A. and Bwakira, L. (2002) Measuring Transparency and Disclosure at Firm-Level in Emerging Markets. Emerging Markets Review, 3, 325-337. 
https://www.sciencedirect.com/science/article/pii/S1566014102000407 https://doi.org/10.1016/S1566-0141(02)00040-7

[7] Klapper, R. and Love, I. (2002) Corporate Governance, Investor Protection and Performance in Emerging Markets. The World Bank, Policy Research Working Paper Series 2818 .

https://www.sciencedirect.com/science/article/pii/S0304405X00000659 https://doi.org/10.2139/ssrn.303979

[8] Jensen, M.C. and Meckling, W.H. (1976) Theory of the Firm: Managerial Behaviour, Agency Costs and Ownership Structure. Journal of Financial Economics, 3, 305-360. https://www.sciencedirect.com/science/article/pii/0304405X7690026X https://doi.org/10.1016/0304-405X(76)90026-X

[9] Ball, R., Kothari, S.P. and Robin, A. (2000) The Effect of International Institutional Factors on Properties of Accounting Earnings. Journal of Accounting and Economics, 29, 1-51. https://www.sciencedirect.com/science/article/pii/S0165410100000124 https://doi.org/10.1016/S0165-4101(00)00012-4

[10] Gul, F. and Qui, H. (2002) Legal Protection, Corporate Governance and Information Asymmetry in Emerging Financial Markets. SSRN Working Paper.

https://papers.ssrn.com/sol3/papers.cfm?abstract_id=298169 https://doi.org/10.2139/ssrn.298169

[11] La Porta, R., Lopez-de-Silanes, F., Shleifer, A. and Vishny, R. (1997) Legal Determinants of External Finance. Journal of Finance, 52, 1131-1150.

https://www.jstor.org/stable/2329518?seq=1\#metadata_info_tab_contents https://doi.org/10.1111/j.1540-6261.1997.tb02727.x

[12] La Porta, R., Lopez-de-Silanes, F., Shleifer, A. and Vishny, R. (1998) Law and Finance. Journal of Political Economy, 106, 1113-1155.

https://www.journals.uchicago.edu/doi/abs/10.1086/250042 https://doi.org/10.1086/250042

[13] Shleifer, A. and Wolfenson, D. (2002) Investor Protection and Equity Markets. Journal of Financial Economics, 66, 3-27.

https://scholar.harvard.edu/files/shleifer/files/ip_equitymarkets.pdf https://doi.org/10.1016/S0304-405X(02)00149-6

[14] Johnson, S. (2002) Coase and the Reform of Securities Markets. International Economic Journal, 16, 187-221.

https://www.tandfonline.com/doi/abs/10.1080/10168730200000001 https://doi.org/10.1080/10168730200080001

[15] Bushman, R., Piotroski, J. and Smith, A. (2004) What Determines Corporate Transparency? Journal of Accounting Research, 42, 207-252.

https://onlinelibrary.wiley.com/doi/abs/10.1111/j.1475-679X.2004.00136.x https://doi.org/10.1111/j.1475-679X.2004.00136.x

[16] Dittmar, A., Mahrt-Smith, J. and Servaes, H. (2003) International Corporate Governance and Corporate Cash Holdings. Journal of Financial and Quantitative Analysis, 38, 111-133.

https://www.jstor.org/stable/4126766?seq=1\#metadata_info_tab_contents https://doi.org/10.2307/4126766

[17] La Porta, R., Lopez-de-Silanes, F., Shleifer, A. and Vishny, R. (2002) Investor Protection and Corporate Valuation. Journal of Finance, 57, 1147-1170. https://onlinelibrary.wiley.com/doi/pdf/10.1111/1540-6261.00457 https://doi.org/10.1111/1540-6261.00457

[18] Rajan, R. and Zingales, L. (1998) Financial Dependence and Growth. American 
Economic Review, 88, 559-587.

https://www.jstor.org/stable/116849?seq=1\#metadata_info_tab_contents

[19] Carlin, W. and Mayer, C. (2003) Finance, Investment and Growth. Journal of Financial Economics, 69, 191-226.

https://www.sciencedirect.com/science/article/pii/S0304405X03001120

https://doi.org/10.1016/S0304-405X(03)00112-0

[20] Demirguc-Kunt, A. and Maksimovic, V. (1998) Law, Finance and Firm Growth. Journal of Finance, 53, 2107-2137.

https://onlinelibrary.wiley.com/doi/full/10.1111/0022-1082.00084

https://doi.org/10.1111/0022-1082.00084

[21] Lombardo, D. and Pagano, M. (1999) Law and Equity Markets: A Simple Model. CSEF Discussion Paper No. 25.

https://papers.ssrn.com/sol3/papers.cfm?abstract_id=209312

https://doi.org/10.2139/ssrn.209312

[22] Lombardo, D. and Pagano, M. (2000) Legal Determinants of the Return on Equity. CSEF Discussion Paper No. 24.

https://papers.ssrn.com/sol3/papers.cfm?abstract_id=209310

https://doi.org/10.2139/ssrn.209310

[23] Bhattacharya, U. and Daouk, H. (2002) The World Price of Insider Trading. Journal of Finance, 57, 75-108.

https://onlinelibrary.wiley.com/doi/10.1111/1540-6261.00416 https://doi.org/10.1111/1540-6261.00416

[24] Hail, L. and Leuz, C. (2006) International Differences in the Cost of Equity Capital: Do Legal Institutions and Securities Regulation Matter? Journal of Accounting Research, 44, 485-531.

https://onlinelibrary.wiley.com/doi/abs/10.1111/j.1475-679X.2006.00209.x

https://doi.org/10.1111/j.1475-679X.2006.00209.x

[25] Coase, R.H. (1960) The Problem of Social Cost. Journal of Law and Economics, 3, 1-44. http://www2.econ.iastate.edu/classes/tsc220/hallam/Coase.pdf https://doi.org/10.1086/466560

[26] Stiglitz, J.E. (1989) Markets, Market Failures, and Development. American Economic Review, 79, 197-203.

https://www.jstor.org/stable/1827756?seq=1\#metadata_info_tab_contents https://doi.org/10.3386/w2961

[27] Coase, R.H. (1992) The Institutional Structure of Production: The 1991 Alfred Nobel Memorial Prize Lecture in Economic Sciences. American Economic Review, 82, 713-719. https://www.jstor.org/stable/2117340?seq=1\#metadata_info_tab_contents

[28] Wallis, J. and North, N. (1986) Measuring the Transaction Sector in the American Economy. In: Engerman, S. and Gailman, R., Eds., Long-Term Factors in American Economic Growth, University of Chicago Press, Chicago, 95-148.

[29] Kaufmann, D., Kraay, A. and Mastruzzi, M. (2003) Governance Matters III: Governance Indicators for 1996-2002. World Bank Policy Research Working Paper.

https://papers.ssrn.com/sol3/papers.cfm?abstract_id=405841 https://doi.org/10.1596/1813-9450-3106

[30] Gordon, M.J. (1959) Dividends, Earnings, and Stock Prices. The Review of Economic Studies, 41, 99-105.

https://www.jstor.org/stable/1927792?seq=1\#metadata_info_tab_contents https://doi.org/10.2307/1927792 
[31] Sharpe, W.F. (1964) Capital Asset Prices: A Theory of Market Equilibrium under Conditions of Risk. Journal of Finance, 19, 425-442. https://doi.org/10.1111/j.1540-6261.1964.tb02865.x

[32] CIA World Factbook. Central Intelligence Agency (Various Years 1996-2002). https://www.cia.gov/library/publications/the-world-factbook 